\title{
STUDI EFIKASI DAN KEAMANAN EKSTRAK AKAR DAN DAUN Calotropis gigantea TERHADAP SEL KANKER KOLON DAN SEL KANKER PAYUDARA SECARA IN VITRO
}

\author{
Roihatul Mutiah \\ ${ }^{I}$ Departement of Pharmacy, Faculty of Medical and Health Sciences, Universitas Islam Negeri \\ Maulana Malik Ibrahim, Malang Indonesia \\ roiha@farmasi.uin-malang.ac.id
}

\begin{abstract}
ABSTRAK
Pengembangan fitofarmakauntuk penyakit kanker sampai saat ini menjadi langkah utama dalam mengatasi kegagalan terapi kanker. Calotropis gigantea adalah salah satu tanaman yang telah terbukti secara ilmiah baik in vitro maupun in vivo sebagai agen kemopreventif. Penelitian ini bertujuan untuk menjelaskan efikasi dan keamanan ekstrak daun Calotropis gigantea (EDCG) dan ekstrak akar Calotropis gigantea (EACG) pada sel normal NIH3T3, sel kanker kolon WiDr dan sel kanker payudara T47D. Dari hasil analisis MTT dan analisis Selectivity Index (SI) didapatkan hasil bahwa Ekstrak etanol daun Calotropis gigantea (EDCG) dapat menghambat pertumbuhan sel kanker kolon WiDr secara selektif (SI>3) namun tidak selektif dalam menghambat pertumbuhan sel kanker payudara T47D (SI<3). Ekstrak etanol akar Calotropis gigantea (EACG) tidak selektif dalam menghambat pertumbuhan sel kanker kolon WiDr dan sel kanker payudara T47D $(\mathrm{SI}<3)$. Oleh karena itu EDCG dapat direkomendasikan sebagai kandidat Fitofarmaka dengan pembuktian lebih lajut melalui uji klinik.
\end{abstract}

Katakunci : Calotropis gigantea, Sel NIH3T3, Sel WiDr, Sel T47D, efikasi, keamanan, Selectivity Index (SI)

\begin{abstract}
Development of phytopharmaca for cancer until now has become a major step in overcoming the failure of cancer therapy. Calotrophis gigantea is one of the scientifically proven plants both in vitro and in vivo as a chemopreventive agent. This study aims to explain the efficacy and safety of Calotropis gigantea leaf extract (EDCG) and Calotropis gigantea root extract (EACG) on NIH3T3 cell, colon cancer cell WiDr and T47D breast cancer cells. From the analysis of MTT and Selectivity Index (SI) analysis showed that ethanol extract of leaf Calotropis gigantea (EDCG) can inhibit selective growth of selective colon cancer cells (SI> 3) but not selective in inhibiting the growth of breast cancer cells T47D (SI $<3$ ). Calotropic gigantea $(E A C G)$ root ethanol extract is not selective in inhibiting the growth of colon cancer cells WiDr and breast cancer cells T47D (SI <3). Therefore EDCG can be recommended as a Phytopharmaca candidate with further proof through clinical trials.
\end{abstract}

Keywords: Calotrophis gigantea, NIH3T3 Cells, WiDr Cells, T47D Cells, efficacy, safety. 


\section{PENDAHULUAN}

Kanker payudaradan kolon termasuk dalam kelompok lima kanker penyebab kematian terbanyak di dunia selain kanker paru-paru, lambung dan hati. Kanker payudara menyebabkan 519.000 kematian pertahun sedangkan kanker kolon menyebabkan 608.000 kematian per tahun [1]. Penelitian di Amerika menyatakan satu dari delapan wanita Amerika terserang kanker payudara dan 30\% dari penderita mengalami kematian [2]. Di Indonesia, prevalensi kanker payudara menduduki peringkat ke-2 setelah kanker leher rahim dan merupakan penyebab kematian utama bagi kaum wanita. Dari semua kasus pada wanita Indonesia, pada tahun 1991 kasus kanker payudara mencapai 17.77\% [3].

Pengembangan pengobatan untuk penyakit kanker sampai saat ini sangat perlu untuk dikembangkan. Hal ini disebabkan karena seringnya terjadi kegagalan terapi kanker baik melalui kemoterapi, pembedahan dan radioterapi. Kegagalan terapi tersebut disebabkan karena terjadinya resitensi sel kanker terhadap obat kemoterapi dan timbulnya efek samping yang sangat serius pada pasien. Efek samping timbul karena obat kemoterapi tidak spesifik hanya membunuh sel kanker namun sel normal juga ikut terbunuh. Pengembangan terapi kanker melalui pengembangan bahan alam baik sebagai agen kemopreventif maupun untuk agen fitofarmaka sangat penting untuk dikembangkan. Karena kelebihan produk bahan alam adalah efek samping yang ditimbulkan lebih kecil dari obat sintesis.

Calotropis gigantea (L.) W.T Aiton(C.gigantea) merupakan tanaman obat tradisional yang tumbuh tersebar di Indonesia. Tanaman ini secara turun temurun telah dimanfaatkan oleh masyarakat Indonsia sebagai obat gatal-gatal, kudis,bisul, batuk, trakhoma, konstipasi (daunnya), asma, mual, nyeri lambung (bunganya), rajasinga, digigit ular berbisa (akarnya), sakit gigi, bengkak-bengkak, radang telinga, cacingan dan disentri [4]. Pada penelitian sebelumnya telah dilaporkan bahwa senyawa calotropon dari bagian akar mempunyai aktivitas sitotoksik terhadap Leukemia K562 dan gastric cancer 7901 [5]; ekstrak etanol daun C.gigantea mampu menghambat pertumbuhan fibrosarcoma secara in vivo pada dosis 100 dan $150 \mathrm{mg} / \mathrm{kgbb}$ dengan mekanisme peningkatan ekspresi caspase-3 [6]. Ekstrak akar C.gigantea mempunyai aktivitas antikanker yang lebih tinggi dibanding bagian daun dan bagian bunga [7]. Fraksi etil asetat dari bagian daun $\left(\mathrm{IC}_{50} 41.79 \mu \mathrm{g} / \mathrm{ml}\right.$ ) dan fraksi diklorometan $\left(\mathrm{IC}_{50} 40.57 \mu \mathrm{g} / \mathrm{ml}\right)$ mempunyai aktivitas sitotoksik yang lebih tinggi dibanding fraksi butanol ( $\left.\mathrm{IC}_{50} 737.74 \mu \mathrm{g} / \mathrm{ml}\right)$ dan air ( $\mathrm{IC}_{50} 8493 \mu \mathrm{g} / \mathrm{ml}$ ) [8].

Oleh karena itu pada penelitian ini dilaporkan tentang hasil uji aktivitas dan keamanan secara in vitro dari Ekstrak Etanol Daun Calotropis gigantea (EDCG) dan Ekstrak Etanol Akar Calotropis gigantea (EACG). Parameter aktivitas antikanker EDCG dan 
EACGdilakukan terhadap sel kanker kolon WiDr dan Sel T47D sedangkan untuk parameter keamanan dilakukan terhadap sel normal fibroblast NIH3T3 untuk menentukansitotoksisitasnya. Selanjutnya ditentukan Selektifitas Indeks dari aktivitas antikanker ekstrak uji.

\section{BAHAN DAN METODE PENELITIAN}

\section{Bahan Uji}

Bahan uji yang digunakan adalah bagian akar dan bagian daun Calotropis gigantea yang didapatkan dari Malang Jawa Timur. Determinasi tanaman dilakukan di Lembaga Ilmu Pengetahuan Indonesia (LIPI) Purwodadi Jawa Timur.

\section{Bahan untuk ekstraksi}

Pelarut yang akan digunakan untuk tahap ekstraksi maserasi adalah etanol 70\% (Merck).

\section{Bahan untuk kultur sel}

Sel kanker yang digunakan pada penelitian ini adalah sel line kanker kolon WiDr dan sel kanker payudara T47D. Sel tersebut diperoleh dari Cancer Chemoprevention Research Centre (CCRC), Fakultas Farmasi Universitas Gadjah Mada dan dari Prof. Masasi Kawaichi, laboratorium of Gene Function in Animal, Graduate School of Biological Science, Nara Institute of Science and Technology.

Sel WiDr dan sel T47D dalam medium Rosewell Park Memorial Institute (RPMI) ditambah dengan 10\% heat-inactivated fetal bovine serum (FBS)(PAA Labortories), $1 \%$ v/v penicillinstreptomicin (Nacalay Tesque), dan 1,0mM L-glutamin (Nacalay Tesque). Kemudian sel dikultur dalam inkubator, pada $5 \% \mathrm{CO}_{2}, 95 \% \mathrm{O}_{2}$ suhu $37^{\circ} \mathrm{C}$.

\section{Bahan uji sitotoksik}

Dimetil sulfoksida (DMSO) digunakan untuk melarutkan Ekstrak Daun Calotropis gigantea (EDCG). Konsentrasi yang digunakan pada penelitian ini maksimal $1 \%$ dalam medium kultur. 0,025\% tripsin dalam medium kultur digunakan untuk memanen sel. Phosphate buffer saline (PBS) digunakan sebagai larutan penyangga pencuci. 3-(4,5-dimetiltiazole-2-il)2,5-difeniltetrazolium (MTT) digunakan sebagai reagen yang bereaksi dengan enzim suksinat dehidrogenase pada sel. 5 Fluorouracil, Doxorubisin sebagai agen kemoterapi dikombinasikan dengan EDCG. 


\section{Alat}

Alat utama yang diperlukan dalam penelitian ini adalah maserator, evaporator, sentrifuse ,tangki nitrogen cair, $\mathrm{CO}_{2}$-Jacketed Incubator, mikroskop fase kontras, Laminar Air Flow cabinet (Nuaire), Elisa reader.

\section{Metode Penelitian}

\section{Ekstraksi}

Dimasukkan 10 bagian simplisia (akar/daun) dengan derajat halus kedalam sebuah bejana, dituangi dengan 75 bagian cairan penyari, ditutup, biarkan selama 5 hari terlindung dari cahaya sambil sering diaduk, diserkai, diperas, ampas dicuci dengan cairan penyari secukupnya hingga diperoleh 100 bagian. Dipindahkan kedalam bejana tertutup, dibiarkan ditempat sejuk, terlindung dari cahaya selama 2 hari. Di enaptuangkan dan disaring. Filtrat yang diperoleh dikumpulkan lalu diuapkan dalam rotary evaporator pada suhu $50^{\circ} \mathrm{C}$. Ekstrak kental yang diperoleh kemudian dikeringkan dan didesikator vakum dan selanjutnya dialiri gas N2 untuk menghilangkan semua sisa pelarut pada ekstrak. Ekstrak etanol dari bagian daunCalotropis gigantea disebut EDCG, Ekstrak etanol dari bagian akar Calotropis gigantea disebut EACG.

\section{Uji aktivitas sitotoksik metode MTT}

Suspensi sel (kanker kolon WiDr, sel T47D, Sel NIH3T3) masing-masing sebanyak $100 \mu \mathrm{L}$ dengan kepadatan $3 \times 10^{4} \mathrm{sel} / 100 \mu \mathrm{L}$ media didistribusikan ke dalam sumuran- sumuran pada 96-well plate dan diinkubasikan selama 24 jam. Setelah diinkubasi, ke dalam sumuran dimasukkan $100 \mu \mathrm{L}$ larutan uji pada berbagai seri konsentrasi. Sebagai kontrol positif ditambahkan $100 \mu \mathrm{L}$ medium kultur, kemudian $100 \mu \mathrm{L}$ cisplatin pada berbagai seri konsentrasi ke dalam sumuran yang telah berisi $100 \mu \mathrm{L}$ suspensi sel. Sebagai kontrol sel ditambahkan $100 \mu \mathrm{L}$ medium kultur ke dalam sumuran yang berisi $100 \mu \mathrm{L}$ suspensi sel dan sebagai kontrol pelarut ditambahkan $100 \mu \mathrm{L}$ DMSO ke dalam sumuran yang berisi $100 \mu \mathrm{L}$ medium kultur dan $100 \mu \mathrm{L}$ suspensi sel dengan delusi yang sesuai dengan delusi konsentrasi larutan uji, kemudian diinkubasi selama 24 jam dalam inkubator dengan aliran $5 \% \mathrm{CO}_{2}$ dan 95\% $\mathrm{O}_{2}$. Pada akhir inkubasi, media kultur dibuang lalu ditambahkan $10 \mu \mathrm{L}$ larutan MTT (5 mg/mL PBS), dan medium diganti dengan $190 \mu \mathrm{L}$ medium RPMI 1640 komplit. Kemudian sel diinkubasi selama 3-4 jam. Reaksi MTT dihentikan dengan penambahan reagen stopper SDS $(100 \mu \mathrm{L})$. Microplate kemudian dibungkus dengan tissue dan diinkubasi selama 1 malam pada suhu kamar dan ruangan gelap. Sel yang hidup bereaksi dengan MTT membentuk warna ungu. Hasil pengujian dibaca dengan ELISA reader pada panjang gelombang $595 \mathrm{~nm}[9]$. 


\section{HASIL DAN PEMBAHASAN}

\section{Analisis hasil aktivitas antikanker EDCG dan EACG terhadap sel kanker kolon WiDr}

dan sel kanker payudara T47D

Tujuan uji aktivitas antikanker EDCG dan EACG terhadap sel kanker kolon WiDr dan sel kanker payudara T47D adalah untuk mengetahui perbandingan efektifitas kedua ekstrak terhadap kedua sel yang berbeda. Dikarenakan efektifitas suatu bahan uji mempunyai efikasi yang berbeda terhadap jenis sel yang berbeda. Aktivitas antikanker EDCG dan EACG terhadap sel kanker kolon WIDr dan sel T47D disajikan pada gambar 1 dan gambar 2.

A

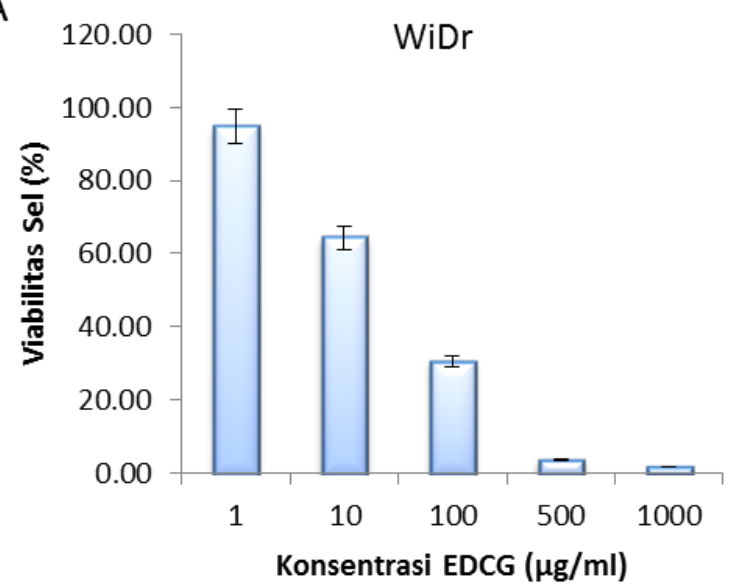

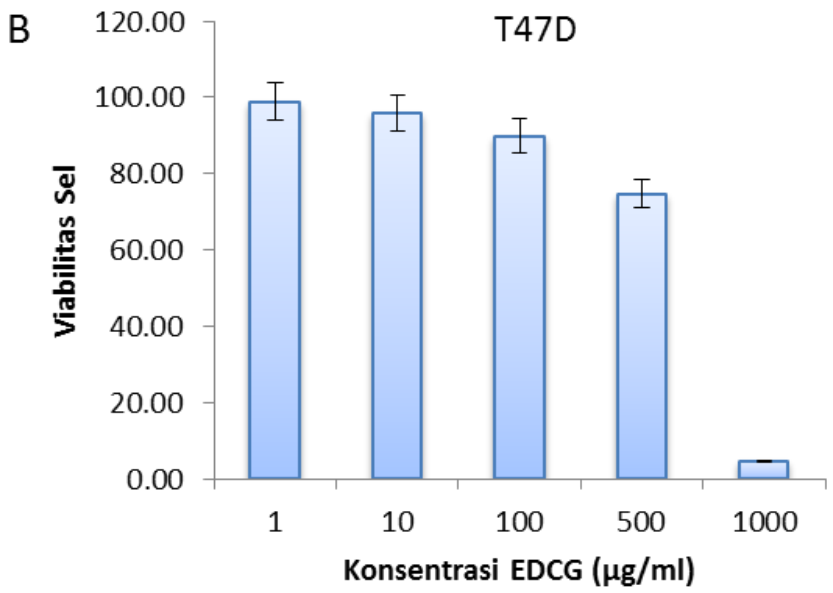

Gambar 1. Perbandingan efek penghambatan pertumbuhan sel akibat : A) perlakuan Ekstrak etanol Daun Calotropis gigantea (EDCG) terhadap sel kanker kolon WiDr; B) perlakuan EDCG terhadap sel kanker payudara T47D dengan metode reduksi MTT. Sel sebanyak $10^{4}$ sel/sumuran ditanam dalam 96 well plate, diinkubasi selama 24 jam dalam media RPMI komplit. Data merupakan representasi dari 3 (tiga) eksperimen yang berbeda dengan hasil yang konsisten dan masing-masing eksperimen dilakukan dengan 3(tiga)x replikasi.

Pada gambar 1 dapat diketahui bahwa perlakuan EDCG terhadap sel kanker kolon WiDr menyebabkan viabilitas sel kanker semakin menurun dengan peningkatan dosis. Sedangkan perlakuan EDCG terhadap sel kanker payudara T47D menunjukkan bahwa peningkatan dosis tidak berpengaruh terhadap viabilitas sel kanker. 

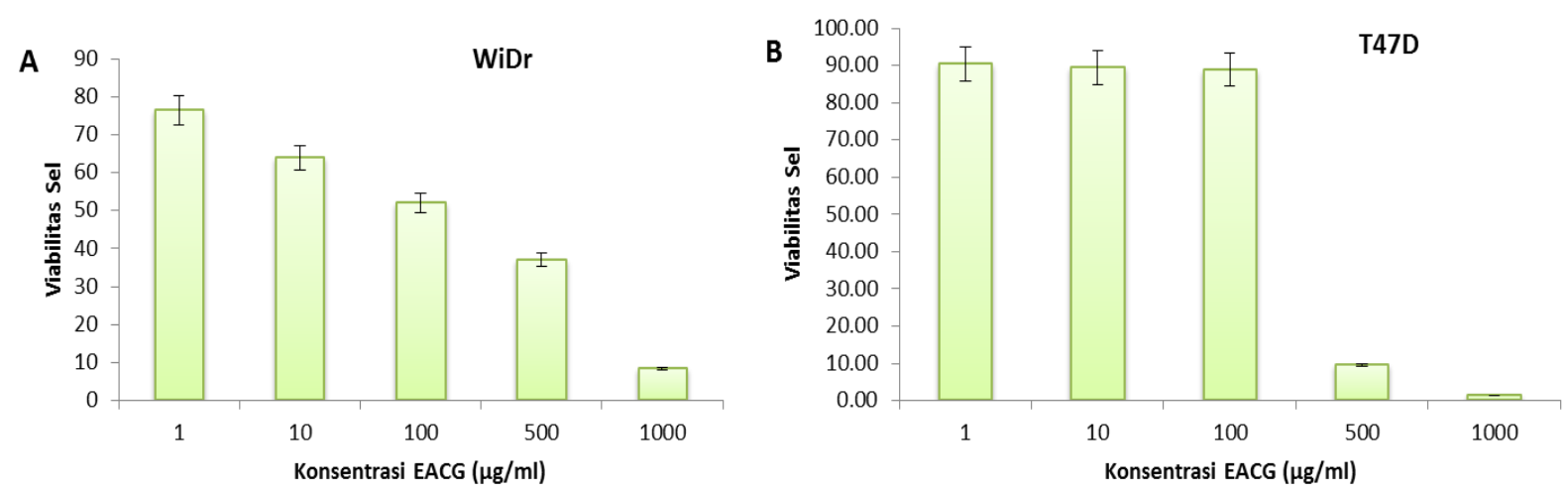

Gambar 2. Perbandingan efek penghambatan pertumbuhan sel akibat : A) perlakuan Ekstrak etanol AkarCalotropis gigantea (EACG) terhadap sel kanker kolon WiDr; B) perlakuan EACG terhadap sel kanker payudara T47D dengan metode reduksi MTT. Sel sebanyak $10^{4}$ sel/sumuran ditanam dalam 96 well plate, diinkubasi selama 24 jam dalam media RPMI komplit. Data merupakan representasi dari 3 (tiga) eksperimen yang berbeda dengan hasil yang konsisten dan masing-masing eksperimen dilakukan dengan 3(tiga)x replikasi.

Gambar 2 di atas menjelaskan tentang perbandingan pengaruh perlakuan ekstrak akar Calotropis gigantean(EACG) terhadap viabilitas sel kanker kolon WiDr dan sel T47D. pada gambar A dapat diketahui bahwa pemberian perlakuan EDCG terhadap sel kanker kolon WiDr dapat menurunkan viabilitas sel seiring dengan peningkatan dosis EDCG. Sedangkan pada gambar B dapat dijelaskan bahwa perlakuan EACG tidak berpengaruh terhadap viabilitas sel kanker payudara T47D yang dibuktikan dengan masih tingginya viabilitas sel sampai dosis $100 \mu \mathrm{g} / \mathrm{ml}$.

\section{Hasil uji sitoksisitas EDCG dan EACG pada sel normal fibroblast NIH3T3}

Hasil uji aktivitas antikanker EDCG dan EACG pada sel kanker kolon WiDr menunjukkan potensi yang cukup tinggi namun terhadap sel kanker payudara T47D tidak menunjukkan adanya aktivitas antikanker. Sebelum dilakukan penelitian lebih lanjut mengenai potensinya sebagai antikanker perlu dipastikan terlebih dahulu efek sitotoksiknya terhadap sel normal. Efek toksik pada sel normal menjadi permasalahan besar pada terapi kanker, berupa efek samping yang dapat menurunkan kualitas hidup pasien. Efek toksisitas EDCG dan EACG di sajikan pada tabel di bawah ini: 
Tabel 1. Rata-rata persen viabilitas sel dan nilai IC $_{50}$ EDCG dan EACGterhadap sel normal fibroblast NIH3T3

\begin{tabular}{|c|c|c|c|c|c|c|c|}
\hline \multirow{2}{*}{$\begin{array}{c}\mathbf{N} \\
\mathbf{0}\end{array}$} & \multirow[t]{2}{*}{ Ekstrak } & \multicolumn{5}{|c|}{$\begin{array}{c}\text { Rata-rata \% viabilitas sel NIH3T3 } \\
\text { pada konsentrasi uji }(\mu \mathrm{g} / \mathrm{mL})\end{array}$} & \multirow{2}{*}{$\begin{array}{c}\mathrm{IC}_{50} \\
(\mu \mathrm{g} / \mathrm{mL})\end{array}$} \\
\hline & & 10 & 100 & 500 & 1000 & 2000 & \\
\hline 1 & $\begin{array}{l}\text { Ekstrak Etanol } \\
\text { daun }\end{array}$ & 86.0 & 57.2 & 47.3 & 34.1 & 7.6 & 203 \\
\hline 2 & $\begin{array}{l}\text { Ekstrak Etanol } \\
\text { Akar }\end{array}$ & 75.4 & 44.3 & 27.1 & 6.6 & 1.6 & 60.8 \\
\hline
\end{tabular}

Untuk keperluan uji sitotoksisitas pada sel normal di gunakan sel NIH3T3, yang merupakan sel fibroblast normal dari embrio tikus. Pemberian perlakuan EDCG dan EACG terhadap sel NIH3T3 menunjukkan adanya efek penekanan pertumbuhan sel mulai dosis $100 \mu \mathrm{g} / \mathrm{ml}$. Profil pengaruh perlakuan EDCG dan EACG terhadap viabilitas sel normal NIH3T3 di sajikan pada gambar di bawah ini:
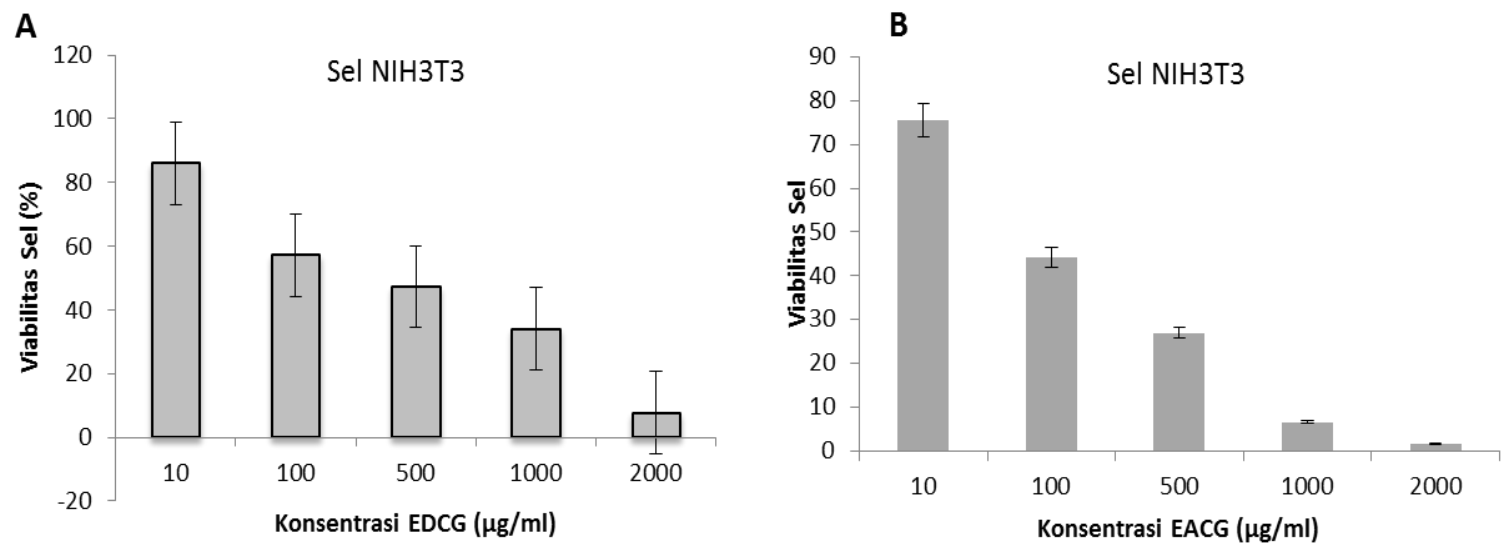

Gambar 3. Pengaruh perlakuan EDCG dan EACG terhadap pertumbuhan sel NiH3T3.

Sel sebanyak $10^{4} \mathrm{sel} / \mathrm{sumuran}$ ditanam dalam 96 well plate, diinkubasi selama 24 jam. Sel diberi perlakuan EDCG dan EACG $(10-2000 \mu \mathrm{g} / \mathrm{mL})$ dengan waktu inkubasi 24 jam. Viabilitas sel ditentukan dengan metode MTT. Analisis t test dengan taraf kepercayaan 95\% menunjukkan konsentrasi yang digunakan dalam penelitian ini $(10-1000 \mu \mathrm{g} / \mathrm{mL})$ tidak menyebabkan penghambatan pertumbuhan sel yang signifikan.Data merupakan representasi dari 3 (tiga) eksperimen yang berbeda dengan hasil yang konsisten dan masing-masing eksperimen dilakukan dengan 3(tiga)x replikasi.

Analisis hasil Selectivity Index (SI) perlakuan EDCG dan EACG terhadap sel kanker kolon WiDr, Sel kanker T47D dan sel normal fibroblast NIH3T3

Tujuan analisis ini adalah untuk mengetahui apakah pemberian EDCG dan EACG bersifat selektif dalam membunuh sel target yaitu sel kanker kolon WiDr dan atau sel kanker payudara T47D. Suatu bahan uji dikatakan bersifat selektif hanya membunuh sel target apabila nilai Selectivity Index (SI) >3 [9]. Nilai Selectivity Index (SI) di peroleh dari 
perbandingan konsentrasi yang dapat membunuh $50 \%$ sel normal $\left(\mathrm{CC}_{50}\right)$ dibandingkan dengan konsentrasi yang dapat membunuh $50 \%$ sel kanker ( $\left.\mathrm{IC}_{50}\right)$. Tabel hasil perhitungan SI disajikan pada tabel 2 dibawah ini.

Tabel 2. Nilai Selectivity Index (SI) dari EDCG dan EACG terhadap sel kanker kolon WiDr dan sel T47D

\begin{tabular}{cccccc}
\hline Sampel & \multicolumn{3}{c}{$\mathrm{IC}_{50} \pm \mathrm{SD}^{*}$} & \multicolumn{3}{c}{$\begin{array}{c}\text { Selectivity Index }(S I) \\
{\left[\mathrm{CC}_{50} / \mathrm{IC}_{50}\right]^{* *}}\end{array}$} \\
\cline { 2 - 6 } & Sel WiDr & Sel T47D & Sel NIH3T3 & Sel WiDr & Sel T47D \\
\hline EDCG & $48.47 \pm 2.45$ & $459.51 \pm 24.2$ & $203.00 \pm 9.89$ & 4.19 & 0.44 \\
EACG & $44.20 \pm 2.30$ & $89.75 \pm 5.67$ & $60.80 \pm 3.67$ & 1.38 & 0.68 \\
\hline
\end{tabular}

*Rata-rata IC50 \pm standart deviasi, eksperimen dilakukan 3 kali replikasi

** Nilai indeks selektifitas $(\mathrm{SI})=\mathrm{CC}_{50} / \mathrm{IC}_{50}$, bahan uji bersifat selektif terhadap sel target jika SI > 3

Berdasarkan data penghitungan indeks selektifitas pada tabel 2 dapat diketahui bahwa yang memiliki nilai SI>3 adalah EDCG terhadap sel kanker kolon WiDr dengan nilai SI yaitu 4.19. Sedangkan EDCG terhadap sel kanker payudara T47D, EACG terhadap sel kanker WiDr dan T47D memiliki nilai SI<3. Hal ini dapat disimpulkan bahwa ekstrak etanol daun Calotropis gigantea (EDCG) bersifat selektif dalam menghambat pertumbuhan sel kanker kolon WiDr namun tidak selektif dalam menghambat pertumbuhan sel kanker payudara T47D. Sedangkan EACG tidak selektif dalam menghambat pertumbuhan sel kanker kolon WiDr dan sel kanker payudara T47D.

\section{KESIMPULAN}

Ekstrak etanol daun Calotropis gigantea (EDCG) dapat mengahambat pertumbuhan sel kanker kolon WiDr secara selektif (SI>3) namun tidak selektif dalam menghambat pertumbuhan sel kanker payudara T47D $(\mathrm{SI}<3)$. Ekstrak etanol akar Calotropis gigantea (EACG) tidak selektif dalam menghambat pertumbuhan sel kanker kolon WiDr dan sel kanker payudara T47D $(\mathrm{SI}<3)$.

\section{UCAPAN TERIMAKASIH}

Peneliti mengucapkan terimakasih kepada RistekDikti atas dana hibah PEKERTI pada penelitian ini. 


\section{DAFTAR PUSTAKA}

[1] American Cancer Society. Global Cancer Facts \& Figures 3rd Edition. Am Cancer Soc. 2015;(800):1-64.

[2] Tjindrabumi D \& Mangunkusumo R. 2002.Cancer In Indonesia, Present and Future. Jpn.J.Clin.Oncol.32

[3] King R.J.B.,2000. Cancer Biology. $2^{\text {nd }}$ edition. School of Biological Science. University of Surrey. Pearson Education. Harlow-England-London-New York. hal.228-231,263-264

[4] Mardisiswojo danRadjakmanugunsudarso . 1968. Cabe Puyang Warisan Nenek Moyang.. p. 4-4.

[5] Wang Z-N, Wang M-Y, Mei W-L, Han Z, Dai H-F. 2008. A new cytotoxic pregnanone from Calotropis gigantea. Molecules. 13(12):3033-9.

[6] Mutiah, R., Griana, T.P., et al., 2016a. The Effect of Calotropis gigantea Leaves Extract on Fibrosarcoma Growth and Caspase 3 Expression .Interational Journal Phamaceutical and Clinial Research, 8(3), pp.167-171.

[7] Mutiah, R., Sukardiman., Widyawaruyanti, A., Zulaikah, S., 2016b. Comparison of Ethanol Extract from Roots Leaves and Flowers of Calotropis gigantea as Anticancer on T47D Breast Cancer Cell Lines. Alchemy; 5(1):1-4.

[8] Mutiah R., Widyawaruyanti A., Sukardiman S. 2017. Cytotoxic effect of crude extract and fraction from Calotropis gigantea leaves on human colon cancer widr cell lines.International Journal of Pharmacy and Pharmaceutical Sciences (IJPPS), 9 (1). pp. 83-86.

[9] Mutiah R. (2014). Pengembangan Fitofarmaka Antikanker “ Panduan Teknik Pengembangan Obat Herbal Indonesia Menjadi Fitofarmaka.Uin Maliki Press.ISBN: 978-602-1190-26-5.pp 50-70 